\title{
An Analysis of the International Research on the Relationship between Prudence and True and Fair View in Financial Reporting
}

\author{
Claudia Cătălina CIOCAN and Iuliana GEORGESCU \\ Alexandru Ioan Cuza University, lasi, Romania
}

Correspondence should be addressed to: Claudia Cătălina CIOCAN; ciocan_claudia_catalina@yahoo.com

Received date: 28 February 2018; Accepted date: 06 May 2018; published date: 27 July 2018.

Academic Editor: Svetlana Mihaila.

Copyright @ 2018. Claudia Cătălina CIOCAN and Iuliana GEORGESCU. Distributed under Creative Commons CC-BY 4.0

\begin{abstract}
It is well known that the main objective of accounting is to build and report a true and fair view in the financial statements. According to accounting rules, this concept implies the application in good faith of all the principles. However, we cannot overlook the fact that there are more or less conflicting situations between some accounting principles, but also between some of them and true and fair view. In this paper, we focus on prudence principle and we aim, starting from an analysis carried out on a number of articles and studies, to characterize the current state of research related to the connection between true and fair view, prudence and financial reporting. Our study was conceived as a meta-analysis combining quantitative and qualitative research with a sample of 152 articles published between 1990 and 2017 in the Science Direct, Wiley and Taylor \& Francis Journals databases
\end{abstract}

Keywords: true and fair view, prudence, conservatism, financial reporting, literature review

\section{Introduction}

In the context in which globalization is a reality of our times, the business world needs to use the same language to adapt to evolution. Undoubtedly, it must be recognized that this language is accounting itself, the only one able to digitally represent the economic reality of an entity. However, accounting was and still is strongly influenced by the existence of two major systems: the Anglo-Saxon accounting system

Cite this Article as: Claudia Cătălina CIOCAN and Iuliana GEORGESCU (2018)," An Analysis of the International Research on the Relationship between Prudence and True and Fair View in Financial Reporting", Journal of Eastern Europe Research in Business and Economics, Vol. 2018 (2018), Article ID 926522, 
and the Continental accounting system, which continues to challenge its primacy in order to save its supremacy in the traditional and international environment (Naciri \& Hoarau 2001). The differences, identified over time between the two systems, have been described as hindering the harmonization of accounting regulations. A first aspect that makes the difference between the two systems is related to the definition of the objectives of financialaccounting information. If for the Continental system the privileged users of the financialaccounting information are banks and tax authorities, for the Anglo-Saxon system, its purpose is to serve the interests of investors, who need to be informed, in order to be able to make the most rational decisions (Ionașcu 2003, p.58). A second aspect is related to the source of accounting law, namely that the Continental accounting system is characterized by the rule of law as opposed to the Anglo-Saxon which relies more on customs and traditions. We also consider the fact that, in the Anglo-Saxon system, the influence of the accounting profession is much higher than in the case of the Continental one, where state regulations are more important than those of accountants. The lack of a general chart of accounts defining the nomenclature and symbolization of accounts in the Anglo-Saxon system is also considered a major difference. The fact that the accountants can set up an account according to their own business needs has not been and will not come too soon a habit adopted by accountants from the Continental environment, trained with the legislative rigor. The tradition of enterprise financing in the two groups of countries is also considered one of the most important factors leading to differences. Countries with AngloSaxon influence are known for the supremacy of funding through stock exchanges, while in the countries that belong to the Continental system this method is still at an early stage, banks being considered as the main source. A last difference, which has as its starting point the issue of the different ways of financing, is found in establishing the fundamental principles for each system
(Ionașcu 2003, p.100). Thus, for Anglo-Saxon companies that are funded through capital markets and for which there must be a high degree of transparency, it is mandatory to respect the substance over form principle in order to give a true and fair view. In the Continental world, there is a confidential attitude which implies prudence as a basic principle. Starting from this last difference, in this paper we propose to characterize the trend of the field regarding the relationship between true and fair view, prudence and financial reporting.

The paper is structured as follows: in the second and third part we present some historical references and interpretations of the true and fair view concept, as well as the relationship between it and the accounting principles, with emphasis on the principle of prudence. In a distinct section we present the research design followed by the study and the results.

\section{Literature Review}

The concept of "true and fair view" or "fair view" has an Anglo-Saxon origin and was first encountered in the form of a combination of the words "correct", "true", "honest" and "total" in the United Kingdom regulations of the 1844 Joint Stock Companies Act (Simo et al. 2013). This concept, despite the efforts made by the theoreticians and practitioners of this field, does not have a unified definition even today, both in the Anglo-Saxon accounting system and in the Continental accounting system. A first interpretation may be considered as the one belonging to Chastney (1975), who asserts that "the true and fair view", a concept of British origin, emphasizes that, in order to achieve a fair picture, financial reporting is obliged to present impartial information in a manner in which will allow the reader to understand it". The closest form to a complete and comprehensive definition for this concept belongs to Lee (1981), who asserts that true and fair view implies the presentation of the accounts 
drawn up in accordance with the General Accepted Accounting Principles, using the most accurate figures, approximate estimates and their arrangement so that the resulting image is the most objective possible, without errors, omissions, distortions or manipulations. Arden (1997) defines it as a dynamic concept, subjected to a continuous rebirth. The author does not believe that a definition or a synonym can be found for this concept, but only a number of its features. Ekholm and Troberg (1998) assert that accountants have not been able to present a definition of the concept, that its application varies across the European Union, differentiated from country to country, and sometimes even from one professional to another, which only emphasizes the impossibility of establishing a unitary definition. According to the two authors, true and fair view reporting is required to provide unbiased information about company values. Alexander and Archer (1998) state that it is impossible to know, to predict exactly what information will be meaningful to users from one year to another; so it is not possible to establish exactly what will be required to convey a true and fair view.

Although the concept is an Anglo-Saxon one, it is now considered a meta-principle of accounting, and some benchmarks for the interpretation of this concept are found in both IAS 1 and 34/2013 Directive. Its acceptance in the continental system took place only after the accession of Great Britain and Ireland into the European Union on January 1st, 1973, when the Fourth Directive was modified and it included the concept. Since then, it has been developed and reached a much higher degree of use in countries belonging to the continental accounting system (Nobes \& Parker 2004). The Fourth Directive imposes the true and fair view requirement by adopting mandatory schemes for drawing up the balance sheet and the income statement and fixing the minimum content of the annex and the management report (CEE 1978). The current 34/2013 Directive requires that financial statements should be prepared on a prudential basis and provides a true and fair view of the assets, liabilities, financial position and profit or loss of the enterprise. According to IAS 1, the financial statements must fairly present the entity's financial position, the financial performance and cash flows and the fair presentation requires accurate representation of the effects of transactions, other events and conditions in accordance with the definitions and recognition criteria for assets, liabilities, revenues and expenses, set out in the Conceptual Framework (IFRS 2013). Lungu (2007) states that continental countries translated this concept by compliance with rules, leading this way to a regulated sincerity. Mateş, Şteţ and Szabo (2006) present the true and fair view, which has as its main feature the primacy of economic reality over the legal form, and its interpretation as a first obstacle in the process of harmonization of accounting structures at international level. In the French accounting literature (Toma 2001), true and fair view is considered to be a concept that evolves temporally and spatially, depending on legislative, political or social changes, and whose definition would impose constraints, setting a notion that is, in fact, an evolutionary character. Feleagă (2006) argues that this is a federal principle that channels the whole set of principles to a certain purpose.

\section{The Relationship between True and Fair View and Accounting Principles}

According to Ionașcu (1997), the construction of the true and fair view of the economic reality is primarily affected by the internal inconsistency of accounting. The author explains that there are more or less conflicting situations between certain accounting principles (e.g. the opposition between the principle of prudence and the going concern), just as it is between certain principles and true and fair view (consistency concept, accrual concept, the going concern concept, and, last but not least, the principle of prudence). Antolinez Collet (1990) asserts that the true and fair view is 
recognized as a statement of intent: the intention of managers to prepare financial statements that faithfully present the company's results, and in order to build this image, the accounting principles apply. In other words, the application of accounting principles leads to the construction of the true and fair view of the company's financial situation. In this paper we address only the relationship between the true and fair view and the principle of prudence because it is considered that this connection is the most problematic. Accounting literature deals with the association between the two principles in two ways: some see it as a conflict, which involves the exclusion of prudence in order to obtain a true and fair view and some as a complementary relationship, which supposes that, by applying prudence, the fair view is obtained. The purpose of this paper is to characterize the state of knowledge regarding the interaction between those two principles and financial reporting.

\section{Research Design and Methodology}

This paper is structured in the form of a meta-analysis that combines quantitative and qualitative research, thus aiming to characterize the state of knowledge regarding the prudence and fair view and their relation to financial reporting. As far as quantitative research is concerned, our approach is a deductive one and seeks to draw conclusions based on the analysis and classification of the identified articles. For the quantitative research, we used the Factorial Correspondence Analysis (FCA) which aims to highlight the associations between the categories of two or more qualitative variables (in our case a first correspondence is between the topic addressed in the paper and the year of publication, and a second one between the topic and the type of the article). The purpose of the FCA was to determine the manner in which the topics discussed during the analyzed period were approached and to determine the topics that were susceptible to an empirical approach as well as those with a theoretical approach. Qualitative research focuses on papers in the accounting, taxation, auditing and management field in order to identify the main research topics for the two concepts discussed and the way in which their relationship affects financial reporting. The methodology for qualitative research is inductive and based on content analysis. For the quantitative analysis we followed a series of steps. Thus, for the beginning we selected the databases from which we collected the articles, then we determined the fields, the period, we selected the articles (the steps followed for the article selection is detailed in table no.1) and the final stage, in which the selected articles were analyzed. The databases from which the articles were selected were: Science Direct, Taylor \& Francis and Wiley Journals, the period proposed for the analysis is between 1990 and 2017 and the database query was done by the keywords: "fair view", "prudence", and "conservatism". For the qualitative study, we called for a new selection (also presented in table no.1), thus retaining only the articles that were considered representative (representativeness being expressed subjectively, depending on the quotation of the journal and the number of citations for every paper). 


\begin{tabular}{|c|c|}
\hline Selection Criteria & $\begin{array}{l}\text { No. of } \\
\text { articles }\end{array}$ \\
\hline \multicolumn{2}{|l|}{ Quantitative analysis } \\
\hline Initial extraction & 3.151 \\
\hline Articles without full access removed & 1.615 \\
\hline Remaining Articles & 1.536 \\
\hline $\begin{array}{l}\text { Articles that do not present in a significant manner the subjects and those } \\
\text { that refer to the fair value removed }\end{array}$ & 1.384 \\
\hline Remaining Articles & 152 \\
\hline Articles included in the quantitative study & 152 \\
\hline \multicolumn{2}{|l|}{ Qualitative analysis } \\
\hline Articles published in unlisted joumals removed & 49 \\
\hline Remaining Articles & 104 \\
\hline $\begin{array}{l}\text { Articles that have less than } 40 \text { citations (according to } \\
\text { (https://scholar.google.com/) removed }\end{array}$ & 69 \\
\hline Representative articles & 35 \\
\hline Articles included in the qualitative study & 35 \\
\hline
\end{tabular}

Source: own processing

After these two selections we retained for our quantitative study a number of 152 articles concerning prudence and fair view (48 articles - Science Direct, 45 - Taylor \& Francis and 54 - Wiley). Of the 152 articles, we selected for the qualitative analysis only the articles that present a minimum number of 40 citations (this number was established by making the average of citations for all the 152 papers taken into consideration for the quantitative study) and which are published in journals with impact factor, 35 articles being retained for these purposes.

\section{Results}

\section{Results - Quantitative Analysis}

Through the quantitative analysis, we aimed to outline an overview of the number and nature of the papers published between 1990 and 2017 on the true and fair view and prudence, in order to determine the journals, the period in which the concepts under discussion were of interest to accountants, the addressed topics for the analyzed papers, the theories used in the research and the type of the paper. In table no. 2 there is a presentation of the journals in which the articles under analysis were published, ordered by decreasing number of articles. 


\begin{tabular}{|c|c|}
\hline$\overline{\text { Journals }}$ & No. of articles \\
\hline European Accounting Review ${ }^{\text {ISI }}$ & 18 \\
\hline Abacus ISI & 15 \\
\hline Joumal Of Business Finance \& Accounting ISI & 14 \\
\hline Accounting And Business Research ${ }^{\text {ISI }}$ & 13 \\
\hline Accounting In Europe & 9 \\
\hline Accounting And Finance ${ }^{\text {ISI }}$ & 8 \\
\hline Joumal Of Accounting And Economics ${ }^{\text {ISI }}$ & 8 \\
\hline Contemporary Accounting Research ${ }^{\text {ISI }}$ & 7 \\
\hline Research In Accounting Regulation & 7 \\
\hline Critical Perspectives Of Accounting ${ }^{\text {ISI }}$ & 5 \\
\hline Modem Law Review ${ }^{\text {ISI }}$ & 5 \\
\hline Procedia Economics And Finance & 5 \\
\hline Advances In Accounting, & 4 \\
\hline China Joumal Of Accounting Research & 4 \\
\hline Procedia - Social And Behavioral Sciences & 4 \\
\hline The British Accounting Review & 4 \\
\hline The Intemational Joumal Of Accounting & 4 \\
\hline Joumal Of Intemational Financial Management And Accounting ISI & 3 \\
\hline Intemational Joumal Of Auditing ${ }^{\text {ISI }}$ & 2 \\
\hline Accounting Forum & 1 \\
\hline Contaduria Y Administration & 1 \\
\hline Corporate Govemance An Intemational Review ${ }^{\text {ISI }}$ & 1 \\
\hline Eco-Management And Auditing ISI & 1 \\
\hline Financial Accountability \& Management & 1 \\
\hline Intemational Review Of Financial Analysis ${ }^{\text {ISI }}$ & 1 \\
\hline Joumal Of Accounting Literature & 1 \\
\hline $\begin{array}{c}\text { Joumal Of Intemational Accounting, } \\
\text { Auditing And Taxation }\end{array}$ & 1 \\
\hline Public Money \& Management & 1 \\
\hline Revista Española De Financiación Y Contabilidad & 1 \\
\hline South African Joumal Of Accounting Research & 1 \\
\hline The Joumal Of Corporate Accounting And Finance & 1 \\
\hline Theoria & 1 \\
\hline & 152 \\
\hline
\end{tabular}

Source: own processing

Regarding the period in which these articles were published, it can be seen from Figure no. 1 that most of the articles were published during 2009-2015. Also, related to the period in which these articles were published, we synthesized which were the topics discussed over the years, as shown in table no. 3 in appendix 1 and graphically depicted in figure no. 2. 


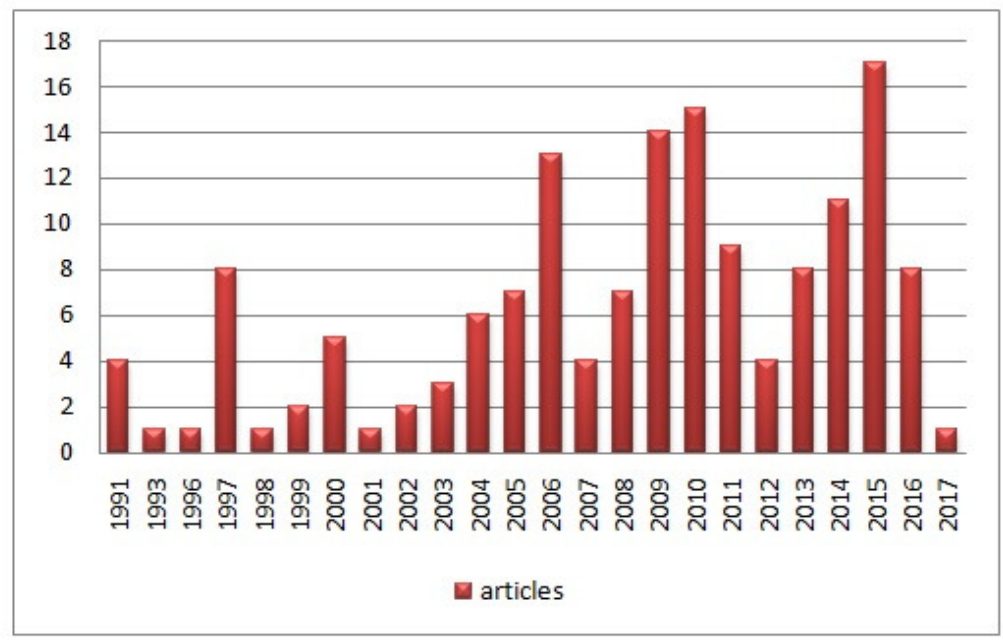

Source: own processing

Fig. 1: Articles published in the period 1990-2017

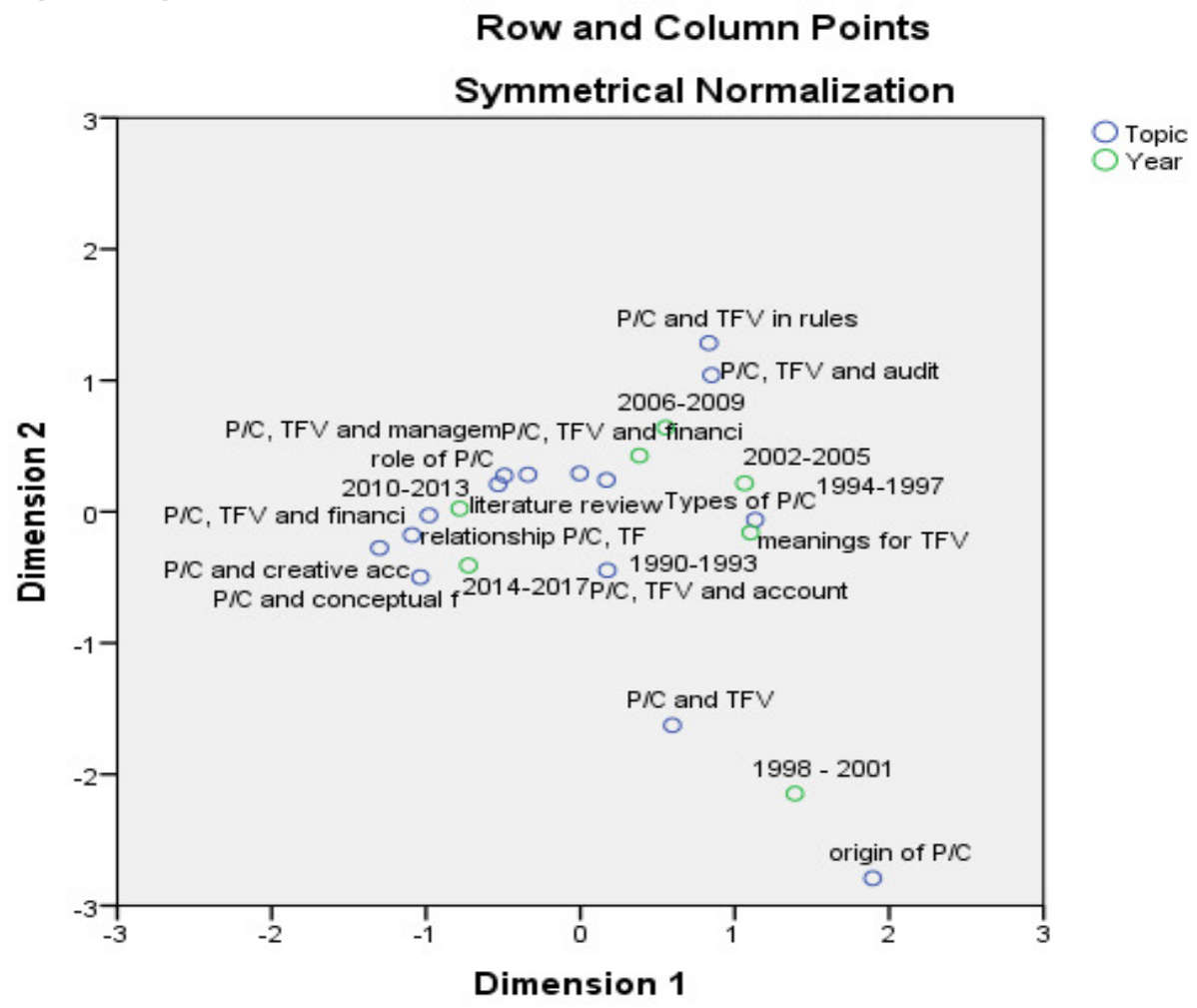

Fig.2: Distribution of topics by year of publication

Source: own processing in SPSS Statistics 23

After analyzing the content of the selected papers, we find appropriate to present some specific topics, for the 1990-2017 period of time. We consider suggestive to split the aforementioned period into smaller intervals, of four years (as detailed in table no. 3 in appendix 1), because we identified many specific topics of interest for the researchers 
and to consider larger intervals of time would dilute the qualitative approach.

In the period 1990-1993, most articles were oriented towards explaining the concept of "true and fair view". Given that the concept is perceived as an undefined one (Walton 1993), its interpretation was a subject of great interest to accountants. With its introduction in the Fourth Directive and its implementation into the national accounting regulations of the European countries, and outside of it (see the case of Norway, Switzerland) we can appreciate that the interest in its interpretation and definition far exceeded the borders of Great Britain. The issue of true and fair view interpretation continues in the following period, 19941997, when besides the topic itself, we encounter papers that addressed the implementation of the true and fair view and prudence into national and international accounting regulations, and the true and fair view role in audit activity.

In the period 1998 - 2001, for the analyzed period, within the range of the chosen sample, we notice that the interest heads toward the way in which the concepts were perceived in national and international regulations, the origins of prudence, as well as the interaction between true and fair view and the existing accounting principles, in particular prudence.

Between 2002 and 2005, the discussions on the two concepts become more and more intense. Most of the papers of that period were focused on the placement of prudence and true and fair view, especially of the latter, in the international and national accounting regulations and also in the principle-based versus rule-based standards debate. This debate arises from the disputes between the two major organizations, IASB and FASB, each having a different approach: FASB are rule-based standards and IASB are principle-based standard. Principle-based standards start from a conceptual framework that provides a general basis for professional guiding instead of a list of rules, while rule- based standards are complemented with specific details meant to satisfy as many possible situations as possible. Rules are sometimes inevitable, and the intention of principle-based standards is not to provide specific guidelines for each possible situation but is directed to the principles of the conceptual framework (Rankin et al. 2012). Concerning the topics discussed, the ambiguity with which the true and fair view is viewed leads to numerous discussions and opinions on its role in standards.

The issue of defining true and fair view and positioning it in the principle-based versus rule-based standards debate remains the topic of interest during the period 20062009 , when most papers addressed the types of conservatism, its role and impact on financial reporting. Some articles also aimed to identify the managerial behavior towards the use of true and fair view as a statutory objective of financial reporting. During this period, an interest of the accountants towards true and fair view in the audit activity can be observed. Enhancing the role of external auditors in guaranteeing the quality of financial reporting has led to the analysis of the use of this concept.

The way in which the concepts were perceived in national and international regulations is also of interest during 20102013, when the majority of the papers address the interaction between prudence, fair view and various elements presented in financial reports, management behavior and a series of literature reviews. For this period we also encountered papers that concern the types of conservatism and its role. Between 2014 and 2017, most papers addressed the issue of prudence and its situation in the Conceptual Framework, followed by the papers addressing the position of the true and fair view and of the prudence in the national and international accounting regulations, the true and fair view objective of the financial reporting, and those concerning the interaction between prudence, fair view and various elements presented in financial reports. The exclusion 
of prudence from the conceptual framework in 2010, the controversies surrounding its removal, and the discussions about its reintroduction in the following years, explain the trends of the literature for this period.

Regarding the typology of the articles included in the analysis, presented in figure no. 4, three categories were considered: theoretical $(48 \%$ of the selected articles), empirical study $(46 \%$ of the selected articles), and literature review (LR 6\% of the selected articles). Thus, from figure no. 3 (detailed in table no. 4 in appendix 1) we observe that the papers that dealt with the role of prudence and true and fair view in principle-based versus rule-based standards debate, those that dealt with the problem of defining and interpreting true and fair view, the exclusion or inclusion of prudence in the conceptual framework and those concerning the approach of the concepts under discussion through the accounting regulations are predominantly of a theoretical nature, and they follow strictly aspects such as history, evolution, definition, interpretation or interaction of concepts, in a theoretical manner, from a critical or interpretative perspective.

The papers that address the management's perception over true and fair view and prudence in financial reporting, the role of prudence and the types of conservatism, the use of concepts in financial reporting, audit, creative accounting and the relationship between the two concepts are subject to empirical studies. The applicability of the prudence principle is the subject of the empirical approach much easier, its effect on financial reporting being much easier to quantify, compared to the true and fair view that allows mostly discussions on the definition and clarification of the concept.

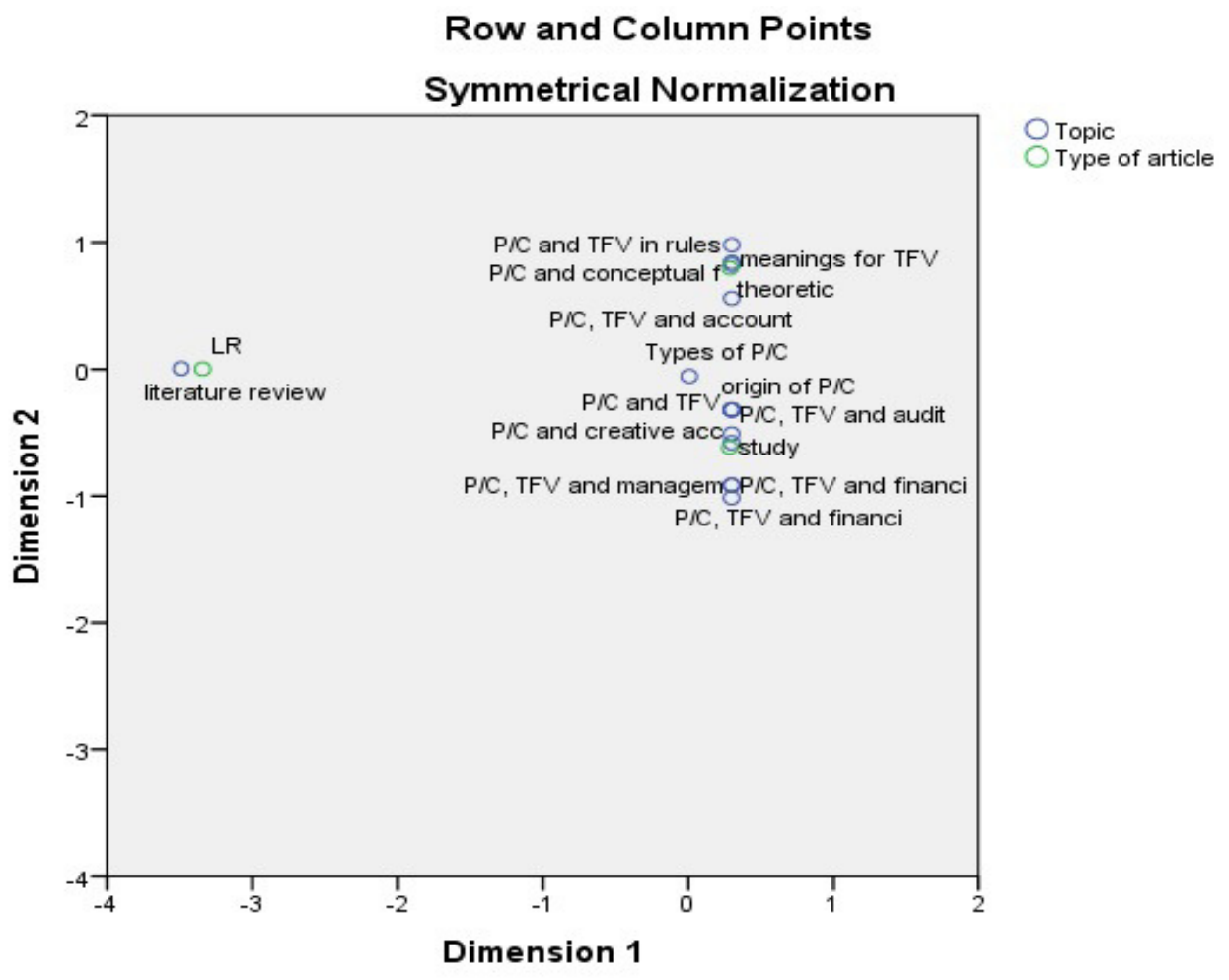

Fig.3: Distribution of topics by type of paper

Source: own processing in SPSS Statistics 23 
The age of true and fair view and the lack of its clear definition can be considered as the basic reasons for which the theoretical papers are predominant.

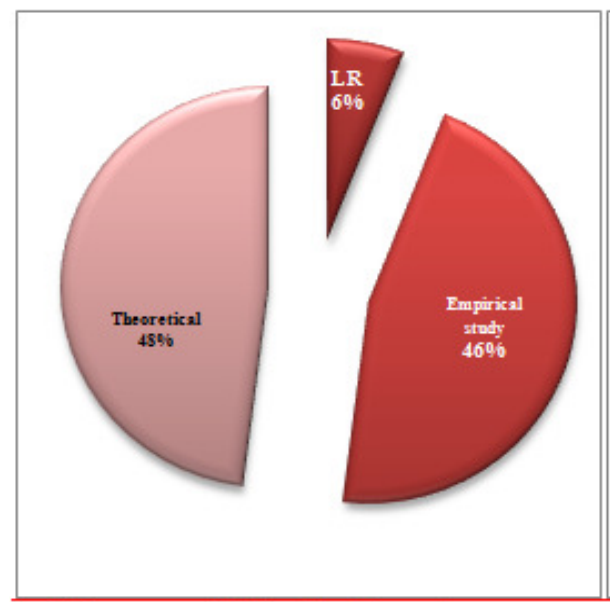

Figure no. 4 Distribution of papers by their type

Source: own processing

A final classification of the papers, shown in Figure no. 5, was made in terms of the number of theories used. Thus, we encountered articles that make reference to a single theory ( $23 \%$ of selected papers), two theories (5\% of the selected papers) and articles without theory $(72 \%$ of the articles selected). The theories these articles refer to are: the agency`s theory (according to which there is an agency relationship between shareholders and managers, a contract expressing the delegation of authority and the transfer of decision-making power (Rankin et al. 2012, p.135)) and information asymmetry theory (according to which managers and shareholders do not have the same possibilities for accessing the information (Rankin et al. 2012, p.140)). An explanation for the use of these theories would be that the shareholders of a company are not, as a rule, directly involved in decision making and managers are employed to represent their interests. But managers have their own interests in the management of an enterprise. In relation to the topics discussed, it can be argued that excessive use of prudence (which in many cases leads to a diminution of distributed dividends) and the

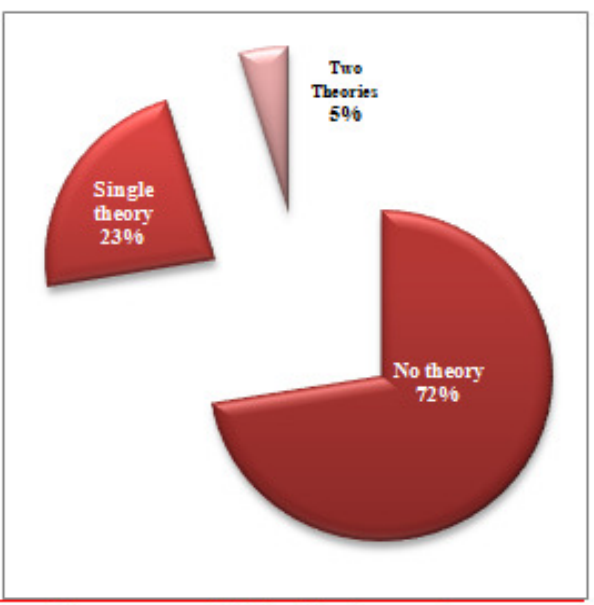

Figure no. 5 Distribution of papers by number of theories Source: own processing

uncertainty of the fair image can cause conflicting situations between shareholders and managers.

\section{Results - Qualitative Analysis}

Through the qualitative analysis, which included only articles considered representative, we aimed to identify the trends in the research for the two concepts discussed. Thus, the following topics were highlighted: placement of the two concepts in principles versus rule-based accounting standards debate; the origin, definition, meanings and interpretations of the topics; the relationship between the true and fair view, prudence and the managerial behavior; the relationship between the accounting principles and the audit activity, including debates about financial reporting.

The connection between the two concepts and financial reporting can be identified in a number of situations, whether we are talking about the impact of prudence on elements of the financial statements or the influence exerted by the true and fair view on accountants. We must bear in mind that the 
application of prudence and the pursuit of the true and fair view affect several elements that will be included in the financial statements. Thus, 8 articles, discussing how prudence and the true and fair view directly or indirectly influence the financial reporting of an enterprise, have been identified.

Alexander and Jermakowicz (2006) consider the nature and alternative perceptions of the notions of principles and rules, and explore the idea of true and fair view presentation as a meaningful requirement in its own right, and as an override. Authors assert that the purpose of financial reporting is to give an understanding, which is not misleading, and that rules, by themselves, are inadequate. They consider that whether or not standards are based on principles, the true and fair view is essential and is considered to be a type A criterion.

Benston and Bromwich (2006) identify several shortcomings addressing principlebased standards. One of these concerns refers to the inclusion of the concept of true and fair view as a requirement for any type of approach in setting standards. The authors assert that true and fair view gives accountants more professional responsibility for the financial statements content and their disclosure gives sufficient transparency for users to understand and, perhaps, challenge its application. They support the inclusion of a true and fair override into GAAP standards, especially when these are rule-based. The usefulness of the true and fair view is based on effective disciplinary measures against managers and auditors, putting the responsibility of accounting judgments on behalf of independent management and auditors.

Kirk (2006) asserts that, if major groups of financial reporting participants differ in their perceptions of standards for financial reporting quality, such as "true and fair view", "fairly presents" and "fair presentation", a financial reporting expectation gap may occur. The article reports the results of a survey designed to explore this potential gap by determining New Zealand financial directors', auditors' and shareholders' perceptions of terms associated with financial reporting quality. The results show that a clear majority of all three groups share similar perceptions of the "true and fair view"; but perceive "true and fair view" to be quite different from "fairly presents" and "fair presentation", terms the New Zealand Institute of Chartered Accountants describes as equivalent to "true and fair view". Thus, there appears to be a perception gap between the surveyed respondents and the Institute. The findings also support a literal rather than a technical interpretation of "true and fair view"; respondents do not perceive 'true and fair view' as compliant with GAAP; and 'true' ("truth" in accounting), the word separating "true and fair view" from terms that include only "fair", may be perceived as a key factor required for financial reporting quality.

Kosmala-MacLullich (2003) addresses the financial reporting issue in relation to the accession to the European Union. She considers that the construct of the true and fair view constitutes a locus of reflection for the establishment of a mutually intelligible foundation for financial reporting in the New Europe, including applicant states for European Union membership. Following a study on the relevant accounting legislation (acts of the Parliament incorporating the provisions of the European Directives), she asserts that the true and fair view is a contingent construct which resides in a particular socio-economic, historic and cultural context and is understood differently outside this context.

Kaserer and Klingler (2008) conclude that the economic impact of an accounting system choice, i.e. the choice between a conservative and a true and fair view accounting system, depends on the corporate governance system under which this accounting framework is implemented. As true and fair view accounting necessarily relies on difficult-toverify information, the quality of this information depends on the management 
incentives to disclose reliable information. If such incentives are weak, a true and fair view accounting system might be abused and, hence, produces less reliable information compared to a conservative accounting system. Guay and Verrechia (2006) assert that discussions about conservatism mostly refer to the accounting treatment of difficultto-verify information (which might consist of shocks to the value of R\&D activities, treatment of goodwill, restructuring costs related to plant divestitures, benefits from a brand name etc.) and define conservatism as a more timely recognition of losses than gains as a result of the report between costs and benefits of disclosing verifiable information by managers and/or firms being asymmetric. Gao (2013) presents conservatism as a measurement principle and formalizes the idea that it serves as a guarantee against the opportunistic influence of managers on accounting measurement. The author suggests that a conservative rule is the way to a "neutral" financial reporting under the circumstances of managers' opportunism.

Bushman and Piotroski (2006) focus on financial reporting incentives related to accounting conservatism by empirically analyzing relations between key characteristics of economy-level institutions and one dimension of accounting conservatism, the asymmetric recognition of economic gains and losses into earnings. The authors note that firms in countries with high quality judicial systems reflect bad news in reported earnings faster than firms in countries with low quality judicial systems.

\section{Conclusions}

The purpose of this paper is to characterize the state of knowledge regarding the principle of prudence and the true and fair view objective of financial reporting. The quantitative analysis in this paper highlights the fact that the two concepts addressed are of interest to the accountants given the number of articles identified in the first phase for the period 1990-2017. The origin, evolution of true and fair view, its definition, and the debate on the clarification of this concept led mainly to theoretical articles presenting the views of different authors on how the concept can be perceived by accountants. The applicability of the prudence principle and the quantification of its impact on financial reporting has been the subject for many empirical research studies. Sometimes managers' prudential attitude, which tends to lead to diminishing distributed dividends, is exaggerated and contrary to the interests of shareholders. The conflict between the managers` own interests and the interests of the shareholders highlighted two great theories that could be related to the concepts under discussion, namely the theory of the agency and the information asymmetry theory. Through qualitative analysis, we came to the conclusion that the literature in the analyzed period focused on issues such as: establishing the meanings and interpretations for the true and fair view and prudence, positioning them in the rule-based versus principle-based debate, the managers and auditor's perception on prudence and true and fair view, as well as the relationship between true and fair view and the accounting principles. With respect to financial reporting, we can assert that the place of true and fair view and prudence in the accounting regulations, the role assigned to them and the overall perception of these concepts, as well as the linkage of the prudence principle with the quality of financial information and the fluctuation of stock prices on the capital market have been identified as issues that may lead to changes in the financial reporting of a company.

From the qualitative analysis strictly focused on the relation between the two concepts and the financial reporting, the following ideas can be drawn: the purpose of financial reporting is to provide an understanding of the real situation of the company, which should not be misleading; the true and fair view can be considered a contingent construction that is applicable in a certain socio-economic and cultural context and that 
outside of it can be perceived differently; that a prudent attitude can be considered the path to a "neutral" financial reporting according to the opportunism of managers.

\section{References}

1. Alexander, D. \& Archer, S., 1998. European Accounting guide 3 rd., Miller.

2. Alexander, D. \& Jermakowicz, E., 2006. A True and Fair View of the Principles/ Rules Debate. Abacus, 42(2), pp.132164.

3. Arden, J., 1997. True and fair view: a European perspective. European Accounting Review, 6(4), pp.675-679.

4. Benston, G.J. \& Bromwich, M., 2006. Principles- Versus Rules-Based Accounting Standards: The FASB' s Standard Setting Strategy. Abacus, 42(2), pp.165-188.

5. Bushman, R.M. \& Piotroski, J.D., 2006. Financial reporting incentives for conservative accounting: The influence of legal and political institutions. Journal of Accounting and Economics, 42(1-2), pp.107-148.

6. CEE, 1978. A PATRA DIRECTIVĂ A CONSILIULUI din 25 iulie 1978 în temeiul art. 54 alin. (3) lit. (g) din Tratat, privind conturile anuale ale anumitor tipuri de societăţi.

7. Chastney, J.G., 1975. True and fair view: a study of the history and meaning of the true and fair and a consideration of the impact of the fourth directive, Institute of Chartered Accounts, England.

8. Collet, S., 1990. Imagen fiel y principios contables. Revista española de financiación y contabilidad, XX, pp.351361. Available at: http://dialnet.unirioja.es/desca rga/articulo/44001.pdf.
9. Ekholm, B. \& Troberg, P., 1998. Quo vadis true and fair view? of international accounting, auditing and Taxation. Available at: http://www.sciencedirect.com/scien ce/article /pii/S106195189890009X [Accessed June 6, 2017].

10. Feleagă, N., 2006. Contabilitatea din România la ora convergențelor cu directivele europene şi referenţialul internaţional. Supliment al Revistei de Economie teoretică şi aplicată, pp.89$114 . \quad$ Available at: http://store.ectap.ro/suplimente/supli ment.pdf.

11. Gao, P., 2013. A measurement approach to conservatism and earnings management. Journal of Accounting and Economics, 55(2-3), pp.251-268. Available at: http://dx.doi.org/ 10.1016/j.jacceco.2012.10.001.

12. Guay, W. \& Verrecchia, R., 2006. Discussion of an economic framework for conservative accounting and Bushman and Piotroski (2006). Journal of Accounting and Economics, 42(1-2), pp.149-165.

13. IFRS, 2013. IAS 1.

14. Ionașcu, I., 2003. Dinamica doctrinelor contabilității contemporane, București: Economica.

15. Ionașcu, I., 1997. Epistemlogia contabilității, București: Economica.

16. Kaserer, C. \& Klingler, C., 2008. The accrual anomaly under different accounting standards - Lessons learned from the German experiment. Journal of Business Finance and Accounting, 35(78), pp.837-859.

17. Kirk, N., 2006. Perceptions of the true and fair view concept: An empirical 
investigation. Abacus, 42(2), pp.205235.

18. Kosmala-MacLullich, K., 2003. The true and fair view construct in the context of the Polish transition economy: some local insights. European Accounting Review, 12(3), pp.465-487. Available at: http://dx.doi.org/10.1080/096381803 1000087844.

19. Lee, G.A., 1981. Modern financial accounting, Walton on Thames.

20. Lungu, C.I., 2007. Teorie și practici contabile privind întocmirea și prezentarea situațiilor financiare, București: CECCAR.

21. Mateş, D., Şteţ, M. \& Szabo, I., 2006. Standardizarea sistemelor contabile contemporane în condiţiile globalizării. Revista Annales Universitatis Apulensis, Series. Available at: https://scholar.google.ro/scholar?hl=ro \& $\mathrm{q}=$ STANDARDIZAREA+SISTEMELOR+ CONTABILE+CONTEMPORANE+ÎN+CO NDIŢIILE+GLOBALIZĂRII\&btnG= [Accessed August 1, 2017].

22. Naciri, A. \& Hoarau, C., 2001. A comparative analysis of American and French financial reporting philosophies:
The case for international accounting standards. Advances in International Accounting, 14, pp.229-247. Available at: http://www.scienced irect.com/science/ article/pii/S0897366001140122.

23. Nobes, C. \& Parker, R.H., 2004. Comparative International Accounting 8th ed., Prentice Hall.

24. Rankin, M. et al., 2012. Standard setting. In Contemporary issues in accounting. John Wiley \& Sons.

25. Simo, B., Kamdem, D. \& Wamba, L.D., 2013. Les concepts d'image fidèle et de prudence au cœur d'une ambivalence rhétorique et dialectique: une analyse diachronique Comptabilités, (5), pp.1-12.

26. Toma, C., 2001. Conturile anuale și imaginea fidelă în contabilitatea românească - probleme contabile actuale, concepte, analiză și audit, Iasi: Junimea.

27. Walton, P., 1993. A European true and fair view? Special Section. European Accounting Review, 2(1), pp.49-58. 


\section{Appendix 1}

Table 3: Distribution of topics by year of publication

\begin{tabular}{|c|c|c|c|c|c|c|c|c|}
\hline \multirow[b]{2}{*}{ Topic } & \multicolumn{8}{|c|}{ Year } \\
\hline & 1990-1993 & 1994-1997 & $1998-2001$ & $2002-2005$ & 2006-2009 & $2010-2013$ & 2014-2017 & Active Margin \\
\hline literature review & 0 & 0 & 0 & 2 & 2 & 4 & 3 & 11 \\
\hline meanings for TFV & 3 & 3 & 2 & 2 & 5 & 1 & 1 & 17 \\
\hline origin of $\mathrm{P} / \mathrm{C}$ & 0 & 0 & 2 & 0 & 1 & 0 & 0 & 3 \\
\hline $\begin{array}{l}\text { P/C and conceptual } \\
\text { framework }\end{array}$ & 0 & 0 & 0 & 0 & 1 & 2 & 7 & 10 \\
\hline $\begin{array}{l}\mathrm{P} / \mathrm{C} \text { and creative } \\
\text { accounting }\end{array}$ & 0 & 0 & 0 & 0 & 0 & 2 & 1 & 3 \\
\hline $\mathrm{P} / \mathrm{C}$ and TFV & 0 & 0 & 1 & 1 & 0 & 0 & 1 & 3 \\
\hline $\begin{array}{l}\mathrm{P} / \mathrm{C} \text { and TFV in rules } \\
\text { versus principle debate }\end{array}$ & 0 & 0 & 0 & 3 & 5 & 0 & 0 & 8 \\
\hline $\begin{array}{l}\text { P/C, TFV and accounting } \\
\text { regulations }\end{array}$ & 1 & 3 & 3 & 4 & 3 & 5 & 7 & 26 \\
\hline P/C, TFV and audit & 0 & 2 & 0 & 1 & 5 & 1 & 0 & 9 \\
\hline $\begin{array}{l}\text { PIC, TFV and financial } \\
\text { markets }\end{array}$ & 0 & 0 & 0 & 0 & 1 & 4 & 2 & 7 \\
\hline $\begin{array}{l}\mathrm{P} / \mathrm{C}, \mathrm{TFV} \text { and } \\
\text { management }\end{array}$ & 1 & 0 & 0 & 3 & 2 & 6 & 2 & 14 \\
\hline $\begin{array}{l}\text { relationship PIC, TFV and } \\
\text { other aspects from } \\
\text { financial reporting }\end{array}$ & 0 & 0 & 0 & 0 & 1 & 6 & 4 & 11 \\
\hline role of $P / C$ & 0 & 0 & 0 & 1 & 2 & 3 & 2 & 8 \\
\hline Types of P/C & 0 & 0 & 1 & 1 & 6 & 3 & 2 & 13 \\
\hline $\begin{array}{l}\text { P/C, TFV and financial } \\
\text { reporting }\end{array}$ & 0 & 1 & 0 & 2 & 2 & 1 & 3 & 9 \\
\hline Active Margin & 5 & 9 & 9 & 20 & 36 & 38 & 35 & 152 \\
\hline
\end{tabular}

Source: own processing in SPSS Statistics 23

Table 4: Distribution of topics by type of paper

\begin{tabular}{|c|c|c|c|c|}
\hline \multirow[b]{3}{*}{ Topic } & \multicolumn{4}{|c|}{ Correspondence Table } \\
\hline & \multicolumn{4}{|c|}{ Type of article } \\
\hline & LR & theoretic & study & Active Margin \\
\hline literature review & 11 & 0 & 0 & 11 \\
\hline meanings for TFV & 0 & 12 & 5 & 17 \\
\hline origin of $\mathrm{P} / \mathrm{C}$ & 0 & 1 & 2 & 3 \\
\hline $\begin{array}{l}\mathrm{P} / \mathrm{C} \text { and conceptual } \\
\text { framework }\end{array}$ & 0 & 7 & 3 & 10 \\
\hline $\begin{array}{l}\mathrm{P} / \mathrm{C} \text { and creative } \\
\text { accounting }\end{array}$ & 0 & 1 & 2 & 3 \\
\hline $\mathrm{P} / \mathrm{C}$ and $\mathrm{TFV}$ & 0 & 1 & 2 & 3 \\
\hline $\begin{array}{l}P / C \text { and TFV in rules } \\
\text { versus principle debate }\end{array}$ & 0 & 6 & 2 & 8 \\
\hline $\begin{array}{l}\mathrm{P} / \mathrm{C}, \mathrm{TFV} \text { and accounting } \\
\text { regulations }\end{array}$ & 0 & 16 & 10 & 26 \\
\hline P/C, TFV and audit & 0 & 3 & 6 & 9 \\
\hline $\begin{array}{l}\text { P/C, TFV and financial } \\
\text { markets }\end{array}$ & 0 & 1 & 6 & 7 \\
\hline $\begin{array}{l}\mathrm{P} / \mathrm{C}, \mathrm{TFV} \text { and } \\
\text { management }\end{array}$ & 0 & 2 & 12 & 14 \\
\hline $\begin{array}{l}\text { relationship P/C, TFV and } \\
\text { other aspects from } \\
\text { financial reporting }\end{array}$ & 0 & 3 & 8 & 11 \\
\hline role of $\mathrm{P} / \mathrm{C}$ & 0 & 2 & 6 & 8 \\
\hline Types of P/C & 1 & 5 & 7 & 13 \\
\hline $\begin{array}{l}\mathrm{P} / \mathrm{C} \text {, TFV and financial } \\
\text { reporting }\end{array}$ & 0 & 1 & 8 & 9 \\
\hline Active Margin & 12 & 61 & 79 & 152 \\
\hline
\end{tabular}

Source: own processing in SPSS Statistics 23

Claudia Cătălina CIOCAN and Iuliana GEORGESCU (2018), Journal of Eastern Europe Research in Business and Economics, DOI: 10.5171/2018.926522 
Appendix 2 Abbreviations

\begin{tabular}{|l|l|}
\hline EU & European Union \\
\hline FASB & Financial Accounting Standard Board \\
\hline IASB & Intemational Accounting Standard Board \\
\hline IFRS & Intemational Financial Reporting Standards \\
\hline P/C & Prudence/ Conservatism \\
\hline TFV & True and Fair View \\
\hline
\end{tabular}

Source: own processing 